Krzysztof Kasianiuk

Collegium Civitas

\title{
Zespoły poselskie i parlamentarne jako formy samoorganizacji parlamentarzystów. Wyniki polskich badań eksploracyjnych
}

DOI: $10.19195 / 1643-0328.20 .9$

Słowa kluczowe: zespoły parlamentarne, samoorganizacja, parlamentarzyści, Polska

\section{Wprowadzenie}

Czy parlamentarzyści byliby w stanie współpracować, gdyby zniknęły kluby parlamentarne? Czy polscy posłowie i senatorowie zorganizowaliby się w inny niż partyjno-klubowy sposób, a jeżeli tak, to na jakiej zasadzie by to przebiegało? Te pytania w stabilnym demokratycznym państwie wydają się brzmieć dość abstrakcyjnie. Stają się jednak bardziej uzasadnione $\mathrm{w}$ sytuacji braku legitymizacji porządku politycznego ${ }^{1}$. W istocie dotykają bowiem kilku ważnych problemów związanych z działaniem politycznym w państwach demokratycznych, takich jak na przykład rozliczalność władzy publicznej czy efektywność, rozumiana jako zdolność do podejmowania publicznych decyzji $\mathrm{w}$ przewidzianych organizacyjnie ramach $^{2}$.

1 Tekst ten był kończony w czasie, kiedy to w Polsce, po wyborach parlamentarnych w 2015 roku pojawił się konflikt wokół Trybunału Konstytucyjnego. Początkowy spór dotyczący prawomocności wyboru kilku sędziów TK przerodził się w spór dotyczący pierwszeństwa i konsekwencji funkcjonujących w Polsce demokratycznych zasad ustrojowych, takich jak „wola narodu” i „państwo prawa”.

${ }^{2}$ Przenikanie się problematyki organizacyjnej ze sferą polityczną pojawia się między innymi w odniesieniu do empirycznych badań nad modelami legislatyw czy systemów politycznych jako takich. Por. Z. Machelski, Modele parlamentów dwuizbowych. Ujęcie porównawcze, „Wrocławskie Studia Politologiczne” 2012, nr 12, s. 148-166; B. Kaczmarek, „Politologia organizacji”? „Organizatologia polityki”? Polityka w świecie organizacji i organizacyjny sens polityki a ich badanie, „Studia Politologiczne” 2010, nr 17, s. 89-128; A.H. Birch, The Concepts and Theories of Modern Democracy, London-New York 1995; J.M. Colomer, Disequlibrium institutions and pluralist democracy, „Journal of Theoretical Politics” 13, 2001, nr 3, s. 235-248; D. Easton, A Systems Analysis of Political Life, Chicago-London 1979; A. Antoszewski, R. Herbut, Systemy polityczne współczesnego świata, Gdańsk 2001. 
Refleksja nad postawionymi tu pytaniami byłaby trudna, gdyby za punkt wyjścia analizy miała służyć obserwacja współczesnej polskiej sceny politycznej, prezentowana w mediach masowych, zwłaszcza w okresie od 2005 roku do chwili obecnej. Obserwacja ta stałaby się dobrym uzasadnieniem dla wątpliwości co do zdolności polskich polityków do prowadzonej samodzielnie, konstruktywnej debaty nad sprawami istotnymi dla kraju i możliwości względnie trwałej akceptacji wspólnych decyzji. Ich działania wydają się często bowiem wypadkową celów partii i celów liderów partyjnych. Z kolei silny konflikt o władzę, dotychczas głównie pomiędzy dwiema dominującymi partiami - Platformą Obywatelską oraz Prawem i Sprawiedliwością - nie tylko na trwałe wpisuje się w krajobraz parlamentaryzmu, ale i może się przyczyniać do marginalizowania znaczenia indywidualnych parlamentarzystów. Sytuacja zdaje się nie zmieniać również po wyborach w 2015 roku, na podstawie których w polskim parlamencie pojawiły się nowe ugrupowania (Nowoczesna oraz Kukiz'15), a rola niektórych partii została zmarginalizowana (PSL i SLD) $)^{3}$. Wydaje się zatem, że w polskim przypadku, partie polityczne oraz ich odpowiedniki parlamentarne w postaci klubów i kół parlamentarnych, nadal są nieodzownym elementem systemu politycznego, pozwalającym mu trwać i zachować względną stabilność.

Ponadto, za brakiem możliwości pozapartyjnego i pozaklubowego działania politycznego parlamentarzystów w polskiej legislatywie przemawia argument, że - od strony technicznej - prawdopodobnie nie byłoby możliwe efektywne przekładanie woli 560 osób (biorąc pod uwagę zarówno Sejm, jak i Senat), o określonym poziomie ambicji politycznych, na jakiekolwiek decyzje publiczne. Rozbieżność interesów i celów tych osób mogłaby się okazać zbyt wielka, nawet w sytuacji gdyby odpowiednio zmodyfikowano regulaminy obu izb. Dążenie do zdominowania reszty uczestników procesu politycznego w parlamencie mogłoby przesłonić posłom i senatorom potrzebę podejmowania właściwych merytorycznie decyzji. Trudno byłoby również stwierdzić, kto w gruncie rzeczy jest odpowiedzialny za decyzje lub ich brak w konkretnym momencie, skoro decyzje takie - każdorazowo wyrażone w wyniku głosowania - mogłyby być legitymowane przez inną większość parlamentarną. Ponadto, konieczność organizacji we względnie trwałe struktury ma wynikać między innymi z faktu zróżnicowania jednostek i pluralizmu ich interesów. W myśl tej argumentacji, to partie są w stanie odpowiednio jednoznacznie i silnie definiować wspólne interesy oraz podtrzymywać wysiłek na rzecz ich realizacji.

Znaczna część współczesnych koncepcji dotyczących organizacji partii politycznych podkreśla przy tym, że zachodzą w niej procesy prowadzące do względnej instytucjonalizacji i autonomizacji względem otoczenia społecznego i politycznego oraz wzmacnia się formalizacja struktury wewnętrznej ${ }^{4}$. To z kolei usztywnia działanie tych form i wyklucza możliwość zaistnienia procesów samoorganizacyjnych.

${ }^{3}$ O ile w Sejmie PSL nadal funkcjonuje w bardzo okrojonym składzie, o tyle SLD nie znalazło w nim już swoich reprezentantów.

${ }^{4}$ Na przykład Robert Michels wykazywał, że partiami politycznymi rządzi dość uniwersalne prawo oligarchizacji (Por. R. Michels, Oligarchiczne tendencje organizacji, [w:] Władza i społeczeństwo, red. J. Szczupaczyński, Warszawa 1995, s. 142-148). Podobną wymowę ma model partii kadrowej Maurice’a Duvergera 
Celem tego tekstu jest próba odpowiedzi na pytanie, czy w demokratycznym, dwuizbowym parlamencie, takim jak polski, mogą zachodzić procesy samoorganizacyjne. Z jednej strony istnieją bowiem wyniki badań, które sugerują, że partie nie muszą stanowić warunku sine qua non organizacji parlamentu ${ }^{5}$. $Z$ drugiej zaś, jak wskazują niektórzy badacze, w państwach postkomunistycznych, takich jak Polska, system partyjny - a wraz z nim i organizacja wewnętrzna partii - ciągle się przekształca ${ }^{6}$. To ostatnie zaś może świadczyć o trwających wciąż wzmożonych procesach adaptacyjnych systemu politycznego, tak jak opisywał je w analizie życia politycznego David Easton ${ }^{7}$. W końcu też, w polskim parlamencie pojawiło się zjawisko, którego skala każe zastanowić się nad tym, czy podejście partyjno-klubo-centryczne powinno być dominujące $\mathrm{w}$ analizach zachowań politycznych parlamentarzystów. Jest to znaczący wzrost - i to zaledwie w ciągu trzech kadencji - liczebności zespołów parlamentarnych, tj. szczególnej formy działania parlamentarnego opartego na dobrowolności. Okazuje się, że o ile na początku transformacji liczba zespołów oscylowała wokół kilkunastu w kadencji ${ }^{8}$, o tyle na koniec VII kadencji Sejmu ich liczba sięgnęła $163^{9}$.

Dlatego najpierw zostanie tu zaprezentowana analiza teoretyczna zagadnienia samoorganizacji, oparta na cybernetycznej koncepcji Williama Ross Ashby’ego, a więc pochodząca spoza głównego nurtu badań politologicznych. Zakłada się bowiem, że zabieg taki pomoże rzucić szczególnego rodzaju światło na charakter parlamentaryzmu w Polsce. Następnie, zmodyfikowana i zoperacjonalizowana definicja samoorganizacji zostanie ukazana jako rama analityczna dla badania empirycznego polskich zespołów poselskich i parlamentarnych lat 2007-2011. Wreszcie, zrelacjonowane zostaną wyniki badań eksploracyjnych, przeprowadzonych $\mathrm{z}$ użyciem metod jakościowych, w ramach otwartego schematu badawczego.

\section{Samoorganizacja w parlamencie jako problem badawczy}

Wydaje się, że przytoczone na początku pytania o zdolność indywidualnych parlamentarzystów do współpracy, niezależnie od klubów i partii politycznych, docierają bardzo głęboko. Z jednej strony, sięgają one do problemu charakteru i warunków zorganizowanego działania zbiorowego wśród ludzi w ogóle. Z drugiej strony, w demokracji odnoszą

(Por. M. Duverger, Political Parties. Their Organization and Activity in the Modern State, New York-London-Sydney 1965). Z kolei, na cechy kartelizacji partii wskazywali między innymi Richard Katz i Peter Mair (Por. R. Katz, P. Mair, Changing models of party organization and party democracy, „Party Politics” 1, 1995, nr 1, s. 5-28).

${ }^{5}$ Dotyczy to małych wspólnot politycznych, na przykład Palau (Por. W.P. Veenendaal, How democracy functions without parties: the Republic of Palau, „Party Politics” 1, 2016, nr 22, s. 27-36).

${ }^{6}$ K. Sobolewska-Myślik, B. Kosowska-Gąstoł, P. Borowiec, Struktury organizacyjne polskich partii politycznych, Kraków 2010, s. 21.

7 D. Easton, op. cit., passim.

8 Informacje przekazane przez pracowników Kancelarii Sejmu w lipcu i sierpniu 2014 roku.

9 Patrz: Archiwum Sejmu Online, Zespoły parlamentarne, http://www.sejm.gov.pl/sejm7.nsf/agent. xsp?symbol=ZESPOLY\&NrKadencji=7 (dostęp: 16.11.2015). 
się do problemu indywidualnego sprawstwa obywatela $\mathrm{w}$ sferze publicznej oraz rozwiązań instytucjonalnych mających owo sprawstwo zapewniać.

$\mathrm{Z}$ pojęciem samoorganizacji w naukach politycznych zwykło się kojarzyć przede wszystkim tak zwaną „oddolną inicjatywę” obywateli. Mają oni sami się organizować, aby wspólnie realizować swoje indywidualne lub wspólne cele. Celem takiej samoorganizacji może być na przykład jednorazowy wpływ na określone decyzje publiczne (tak było na przykład w sytuacji grupy opiekunów osób niepełnosprawnych „okupujących" Sejm), oddziaływanie na charakter funkcjonowania systemu politycznego (tak jak w przypadku "Solidarności”, jako oddolnego ruchu o charakterze politycznym w 1980 roku), a nawet całkowita zmiana zasad i kształtu systemu politycznego (np. zgromadzenia ludności w trakcie tzw. „Arabskiej Wiosny” czy uczestnictwo w działaniach proeuropejskich i antyprezydenckich na ukraińskim Majdanie) ${ }^{10}$. Na pewnym poziomie analizy, za formy samoorganizacji można również uznać bardziej systematyczne działania obywatelskie, na przykład ich zaangażowanie w działalność organizacji pozarządowych. $\mathrm{Z}$ pewnością też, samoorganizacja jest kategorią procesu, który bywa postrzegany jako czynnik przeciwdziałający bolączkom współczesnego systemu politycznego ${ }^{11}$.

W gruncie rzeczy, trudno jest jednak stwierdzić, kiedy w sferze politycznej pojawia się proces samoorganizacyjny. Nie wiadomo bowiem, jak można trafnie ocenić, czy na przykład samo występowanie wysoce aktywnych jednostek (np. liderów społecznych działających w sferze publicznej) albo też powszechnie akceptowanej idei już jest, czy też może jeszcze nie jest, jakąś formą wpływu na określoną zbiorowość polityczną.

Jednocześnie, bardzo rzadko mówi się w literaturze politologicznej o samoorganizacji osób już funkcjonujących w ramach instytucji publicznych, a tym bardziej stricte politycznych, takich jak parlament ${ }^{12}$. Wydaje się, że samo wejście $\mathrm{w}$ sferę publiczną wyklucza możliwość zaistnienia, a tym samym i analizowania procesów o charakterze samoorganizacyjnym ${ }^{13}$. W tym kontekście, o ile można jeszcze rozpatrywać partie polityczne, jako formy samoorganizowania się obywateli w celu zdobycia i utrzymania

$10 \mathrm{ml}$, IAR, Opiekunowie niepetnosprawnych pójdą pod Sejm!, http://www.fakt.pl/protest-opiekunowniepelnosprawnych-doroslych,artykuly,452132,1.html (dostęp: 26.03.2014); A. Dzisiów-Szuszczykiewicz, „Arabska wiosna” - przyczyny, przebieg i prognozy, „Bezpieczeństwo Narodowe” 2011, nr 18, s. 41-56; A. Mielczarek, Ruch "Solidarności” w świetle teorii ruchów społecznych, Tekst zaprezentowany na seminarium „Solidarność - nowe podejścia do analizy ruchu społecznego”, Collegium Civitas, Warszawa, 9 stycznia 2012, http://www.civitas.edu.pl/pub/nasza_uczelnia/seminarium_solidarnosc/Mielczarek-tekst-9.01. pdf (dostęp: 14.09.2014).

11 P. Sadura, Samoorganizacja się sama nie zrobi, „Krytyka Polityczna”, http://www.krytykapolityczna. pl/Teksty-poza-KP/Sadura-Samoorganizacja-sie-sama-nie-zrobi/menu-id-129.html (dostęp: 7.04.2016); paziem, Droga do ocalenia Polski jest samoorganizacja i samoobrona Polaków!, „Wierni Polsce”, https:// wiernipolsce.wordpress.com/2012/01/25/droga-do-ocalenia-polski-jest-samoorganizacja-i-samoobronapolakow/ (dostęp: 14.09.2014).

12 A. Antoszewski, Wzorce rywalizacji politycznej we wspótczesnych demokracjach europejskich, Wrocław 2004; Zachowania polityczne, red. R.J. Dalton, H.D. Klingemann, R. Markowski, t. 1 i 2, Warszawa 2010; D. Nohlen, Prawo wyborcze i system partyjny. O teorii systemów wyborczych, Warszawa 2004.

13 Por. V.O. Key Jr., Politics, Parties, and Pressure Groups, New York 1958; B. Manin, The Principles of Representative Government, Cambridge 1997; J. Muszyński, Procedury zarzadzania w partiach politycznych, Toruń 2004; Obciążeni polityką. Posłowie i partie, red. W. Wesołowski, Warszawa 2001. 
władzy, o tyle już działalność partii politycznych w parlamencie (a w Polsce działalność klubów i kół parlamentarnych), nie jest dla wielu badaczy obszarem, do którego można by zastosować omawiane tu pojęcie, mimo że przynależność do klubu i koła każdorazowo jest formalnie dobrowolna, a to ze względu na fakt, że posłowie według Konstytucji są przedstawicielami „Narodu”14.

Ograniczone zainteresowanie badaczy problemem samoorganizacji polityków już funkcjonujących w sferze publicznej nie umniejsza jednak znaczącej wagi tego proble$\mathrm{mu}$. Jest on ważny dla zrozumienia systemu demokratycznego jako mechanizmu podejmowania zbiorowych decyzji. W systemie demokratycznym nie jest przecież obojętne, jakie cele polityk ${ }^{15}$ realizuje i w jakiej strukturze podejmuje działanie. Nie jest obojętne, czy jego cele są podporządkowane wyłącznie jego woli i realizowane są przez niego indywidualnie, czy też są one wypadkową działalności organizacji wyższego rzędu (np. w Sejmie i Senacie - klubów i kół poselskich i parlamentarnych).

Skoro w większości badań nad zachowaniami parlamentarzystów zakłada się, że działalność parlamentarzystów jest przede wszystkim wypadkową struktury partyjnej (zaś w Polsce: partyjno-klubowej) i instytucji tworzących ład partyjny (w tym ordynacji wyborczej $)^{16}$, bada się między innymi spójność klubów i partii w parlamencie, poprzez analizę głosowań na poziomie ugrupowań politycznych, na przykład w kontekście ideologicznym i organizacyjnym ${ }^{17}$. Taka sytuacja nie sprzyja wszakże zrozumieniu i przewidywaniu procesów politycznych, ponieważ zawęża pole analizy do jednego $\mathrm{z}$ aspektów działania politycznego, to znaczy struktury działania.

\section{Koncepcja samoorganizacji Williama Ross Ashby'ego}

Pytanie o samoorganizację $\mathrm{w}$ parlamencie to $\mathrm{w}$ gruncie rzeczy pytanie o to, kto $\mathrm{z}$ kim się tam wiąże, jakie formy przybierają owe związki i jakie konsekwencje wywołują. Jeden z najbardziej znaczących przeglądów problematyki dotyczącej procesów samoorganizacyjnych w różnych typach systemów przeprowadził William Ross Ashby na gruncie cybernetyki, czyli nauki o sterowaniu ${ }^{18}$. Ashby używał bardzo ogólnych kategorii analitycznych. W związku z tym jego analizy są ciągłym źródłem rozważań wielu autorów odnoszących się do pojęcia samoorganizacji na gruncie nauk społecznych,

14 „Posłowie są przedstawicielami Narodu. Nie wiążą ich instrukcje wyborców”. Patrz: Art. 104. p. 1 Konstytucji Rzeczypospolitej Polskiej z dnia 2 kwietnia 1997 roku.

15 Dla zachowania zwięzłości zachowano uproszczenie w postaci odwoływania się do tylko jednej formy identyfikacji ról politycznych — rodzaju męskiego rzeczowników.

16 Potwierdzają to wyniki badań między innymi skuteczności legislacyjnej. Patrz: A. Dudzińska, System zamknięty. Socjologiczna analiza procesu legislacyjnego, Warszawa 2015. Por. R. Zubek, K.H. Goetz, Ch. Stecker, Sprawny parlament: wpływ partii i reguł na przewidywalność legislacyjna, Warszawa 2009.

17 Wybrane aspekty funkcjonowania Sejmu w latach 1997-2007, red. J. Sokołowski, P. Poznański, Kraków 2008.

18 W.R. Ashby, Principles of self-organizing system, [w:] Principles of Self-Organization, red. H. von Foerster, G.W. Zopf, jr., New York 1961, s. 255-278. 
choć nie są znane prace korzystające z tej teorii do analizy zachowań parlamentarzystów ${ }^{19}$.

W koncepcji Ashby'ego podstawowymi kategoriami analitycznymi są „elementy” (parts) i relacje między nimi, w szczególności zaś problem „zależności” (conditionality) i „braku zależności” (independence).

Ashby zauważył, że należy rozróżnić dwa podejścia do samoorganizacji. O ile pierwsza perspektywa nie wywołuje według niego dyskusji, ponieważ odnosi się do stwierdzenia faktu (zmiany stanu), o tyle w drugiej dyskusji podlega celowość powołania konkretnego systemu do życia albo działania w określonej formie.

Według pierwszego podejścia, elementy po prostu łączą się w wybranej czasoprzestrzeni. Jest to forma „samo-połączenia” (self-connectedness). Ashby opisuje system samoorganizujący się jako taki, w którym części dotąd rozłączne (albo rozłączone) dążą do połączenia i wspólnego działania. Tego rodzaju samoorganizacja może być określana jako spontaniczna. Spontaniczność zaś jest przez Ashby’ego rozumiana jako nieuregulowana lub niesterowana $\mathrm{z}$ zewnątrz. Wskazuje on na to, że efektem samoorganizacji jest zmiana relacji między elementami, przechodzących od „niezależności” do „zależności” (change from independence between parts to conditionality) ${ }^{20}$.

W tym sensie, na przykład zespoły parlamentarne spełniają postawiony przez Ashby’ego warunek samoorganizacji, ponieważ są formą działania, w ramach której mogą się zrzeszać posłowie i senatorowie z różnych klubów. Innymi słowy, członkowie parlamentu dotąd niepołączeni, albo „niezależni” w sensie przynależności do grupy o charakterze politycznym, stają się od siebie w jakiej mierze „zależni”, ponieważ tworzą wspólnie grupę powołaną w określonym, innym celu.

Według Ashby’ego system można jednak rozpatrywać jako samoorganizujący się także w drugim sensie. W drugim znaczeniu, system samoorganizujący się to taki, który jest w stanie reagować na zakłócenia mające miejsce w otoczeniu dzięki mechanizmowi sprzężenia zwrotnego. Ashby podkreśla, że zmiana stanu „poziomu” organizacji (tj. zmiana ze stanu od "niezależności” do „zależności”) może być także opisywana jako służąca lepszemu dostosowaniu się do otoczenia. Organizacja może być według niego albo „dobra” (good), albo „zła” (bad). Przy tym, rozpatrywany przez tego badacza problem "dobrej” i „złej” organizacji” ma charakter relatywistyczny — żadna organizacja nie jest ani absolutnie „dobra”, ani też „zła”. Może być jedynie lepiej lub gorzej przystosowana do otaczającego ją $\mathrm{w}$ danym momencie środowiska ${ }^{21}$. Dobre dostosowanie do otoczenia, określane jako „stabilność systemu”, pozwala na stosunkowo długie trwanie systemu

19 Na przykład H. Haken, Synergetics. An Introduction, Berlin-Heidelberg-New York-Tokyo 1983; G.M. Weinberg, Myślenie systemowe, Warszawa 1979; K.D. Bailey, Sociology and the New Systems Theory: Toward a Theoretical Synthesis, New York 1994; M. Zelený, K.D. Hufford, The Ordering of the unknown by causing it to order itself, „International Journal of General Systems” 1992, nr 21, s. 239-253.

20 W.R. Ashby, op. cit., s. 267.

21 Ibidem, s. 263. 
w zmiennych warunkach. Zdolność ta jest oparta właśnie na mechanizmie sprzężenia zwrotnego pomiędzy systemem i otoczeniem ${ }^{22}$.

Ashby zauważa przy tym, że przejście od „złej” do „dobrej” organizacji w istocie wyklucza możliwość zaistnienia samoorganizacji w pierwszym opisywanym tu sensie, ponieważ proces ten nie wynika tylko z dążeń samych elementów systemu. Ashby argumentuje, że jeżeli system ma się organizować od „złej” do „dobrej” formy, to może to czynić jedynie w kontekście i w odniesieniu do zmian zachodzących w jego otoczeniu. Według niego, to otoczenie pozwala na organizację i reorganizację systemu do kolejnych form. Innymi słowy, opisywana przez Ashby’ego druga forma samoorganizacji, jak twierdzi, nie może być nazwana w pełni „samoorganizacją”. Wynikając z istnienia i oddziaływania otoczenia, $\mathrm{z}$ definicji nie wynika tylko z wzajemnych oddziaływań poszczególnych elementów.

Natomiast, dyskutując z Ashby'm możliwe wydaje się rozpatrywanie zespołów parlamentarnych jako form samoorganizacyjnych w innym sensie. Otóż, zmiana stanu organizacji ze „złej” do „dobrej” może mieć miejsce właśnie dzięki istnieniu w przestrzeni parlamentu innych typów systemów, w szczególności zaś klubów i kół parlamentarnych. Istnienie klubów i kół parlamentarnych może się przyczyniać do możliwości zaistnienia procesów samoorganizacyjnych, ponieważ kluby i koła — jako otoczenie parlamentarzystów - mogą stymulować posłów i senatorów do działania w alternatywnych formach (np. ze względu na zbyt silne dążenie do utrzymania przez liderów spójności klubu).

Podsumowując, w perspektywie Ashby’ego pojęcie samoorganizacji ma kilka istotnych cech, które pozwalają na przyjęcie tej perspektywy do analizy parlamentaryzmu. W ten sposób stanowią one także dogodny punkt wyjścia, do rozpatrywania zespołów parlamentarnych w kategoriach samoorganizacyjnych, a przez to również do podjęcia próby empirycznej odpowiedzi na zadane na początku pytania. Po pierwsze, samoorganizacja jest procesem zachodzącym pomiędzy różnymi elementami (w parlamencie pomiędzy posłami i senatorami), które w tym samym czasie (np. w trakcie parlamentarnej kadencji) oraz przestrzeni formalnej (np. w ramach uwarunkowań sprawowania mandatu posła i senatora) łączą się, tworząc różne formy organizacyjne (w tym zespoły parlamentarne). Po drugie, koncepcja Ashby’ego zakłada istnienie wielu możliwych typów grup o charakterze samoorganizacyjnym, a ich liczba wynika między innymi z liczby elementów oraz liczby możliwych zachodzących między elementami relacji i związków w przestrzeni parlamentu.

Takie rozumienie samoorganizacji pozwala na rozpatrywanie różnych typów działalności parlamentarnej, w tym też zespołów w polskim Sejmie i Senacie, jako form adaptacji systemu parlamentarnego, do otoczenia politycznego i środowiska społeczno-gospodarczego 23 .

$22 \mathrm{~W}$ przypadku zespołów parlamentarnych czynnikiem zapewniającym stabilność systemu jest każdorazowo jego regulamin. To on pozwala na automatyczną zdolność reagowania systemu na zmiany zachodzące w otoczeniu.

${ }^{23}$ D. Easton, op. cit., s. 17-33. 


\section{Metodologia badania empirycznego}

Celem badania empirycznego było sprawdzenie, czy działania polskich parlamentarzystów mogą być rozpatrywane w kategoriach samoorganizacji. Przyjęto, że zanalizowane zostaną zespoły poselskie i parlamentarne pod kątem obu typów myślenia na temat samoorganizacji wyróżnionych przez Williama Ross Ashby’ego. W szczególności, zespoły były rozpatrywane jako:

- forma samopołączenia dotąd niezależnych od siebie elementów (tu: posłów i senatorów);

- forma wspólnego działania elementów w otoczeniu.

$\mathrm{Na}$ gruncie koncepcji Ashby’ego zdefiniowano samoorganizację w polskim systemie parlamentarnym.

„Samoorganizacja w polskim systemie parlamentarnym jest tu rozumiana jako łączenie się posłów i senatorów w struktury inne niż przewidziane w ustawach, Regulaminie Sejmu i Regulaminie Senatu, a określane tam jako struktury o charakterze »politycznym«, bądź też określane jako organy tychże instytucji”. „Polityczność” struktury jest tu pojmowana stricte formalnie, to znaczy wynika z zapisów Regulaminu Sejmu i Senatu. Przy tym fakt, że zespoły parlamentarne nie są określane przez regulaminy obu izb jako formy aktywności politycznej, nie implikuje, że nie mogą one spełniać takiej roli. Wyniki badania empirycznego potwierdzają, że zespoły mogą nosić różny, w tym również polityczny, charakter.

Włączone w zakres tej definicji są 1) zespoły poselskie 2) grupy bilateralne, 3) zbiorowości posłów wspólnie składających projekt ustawy, 4) grupy posłów wspólnie składających interpelację, 5) zapytania i 6) pytania, a także 7) zbiorowości głosujące doraźnie tak samo, niezależnie od rekomendacji klubu czy koła poselskiego lub parlamentarnego. Natomiast wyłączono z definicji te grupy, które a) są traktowane przez regulaminy jako organy parlamentu (np. Prezydium Sejmu, Konwent Seniorów i jego odpowiedniki w Senacie, a także komisje) oraz b) grupy powoływane w regulaminach obu izb na zasadzie „politycznej” (tj. kluby i koła poselskie i parlamentarne ${ }^{24}$ ).

Należy podkreślić, że w efekcie zastosowania przytoczonej definicji nie miało być możliwe zrozumienie czynników determinujących procesy samoorganizujące w parlamencie. W trakcie badania przyjęto, że procesy samoorganizacyjne mogą zachodzić $\mathrm{z}$ bardzo różnych powodów. Przeprowadzone badanie miało tylko stanowić pierwszy, rozpoznawczy krok na polu analizy samoorganizacji. Sposób użycia dostępnych materiałów empirycznych był w nim równie istotny, jak sformułowana na jej użytek koncepcja samoorganiazacji. Samoorganizacja była kategorią osiową dla badania, a jej definicję operacyjną skierowano na opis określonego stanu w określonej czasoprzestrzeni.

Samoorganizacja parlamentarna $w$ relacjonowanym badaniu była formą uporządkowania działania posłów i senatorów w sposób, który wprawdzie ma miejsce w ramach i na podstawie obowiązujących regulacji, stanowi jednak wynik dostrzegania przez posłów i senatorów przestrzeni wolności i sprawstwa w parlamencie.

24 Art. 8, p. 4. Regulaminu Sejmu brzmi: „Poseł może należeć tylko do jednego klubu poselskiego lub koła poselskiego”. Podobnie skrótowy jest Regulamin Senatu - tu art. 21 p. 6 brzmi: „Senatorowie mogą tworzyć w Senacie zespoły zorganizowane na innych zasadach niż określone w ust. 1”. 
W rezultacie tak zarysowanej koncepcji samoorganizacji dokonano jej uszczegółowienia i dostosowania do obszaru parlamentaryzmu. Zespoły miały być zatem badane w dwóch wymiarach:

1. Forma samopołączenia dotąd niezależnych od siebie w określonym wymiarze posłów i senatorów. „Niezależność” odnosi się tu do przynależności do klubu lub koła parlamentarnego.

2. Forma celowego działania posłów i senatorów w otoczeniu parlamentarnym. „Celowość” odnosi się do innych niż określane przez regulaminy izb jako przynależne klubom i kołom parlamentarnym.

Przedmiotem prezentowanego badania były zespoły poselskie i parlamentarne. W zakres przedmiotowego badania weszły jedynie zespoły działające w Sejmie VI i Senacie VII kadencji, które rozpoczęły pracę 5 listopada 2007 roku i zakończyły 7 listopada 2011 roku. Wybór ten wynikał z kilku przesłanek, przede wszystkim związanych z dostępnością danych. Po pierwsze, w poprzednich kadencjach było zdecydowanie mniej zespołów. Po drugie, zanalizowano dane źródłowe pochodzące z kadencji, w której odnotowano znaczący wzrost liczebności i możliwe było zgromadzenie porównywalnych danych. W przyjętym okresie powstało na tyle dużo zespołów, by zakładać, że różnice będą miały więcej niż jednostkowy charakter, a więc że możliwe będzie wychwycenie pewnych regularności i odpowiedzi na pytania o charakterze eksploracyjnym (w tym czasie powstało 66 zespołów poselskich i parlamentarnych). Po trzecie, w Archiwum Senatu odnotowano istnienie tylko jednego zespołu senackiego ${ }^{25}$, stąd zespoły senackie wyłączono $\mathrm{z}$ badania ${ }^{26}$. Z badania wyeliminowano ponadto „Zespół parlamentarny ds. przestrzeni kosmicznej", którego działalność trudno jest zaklasyfikować ${ }^{27}$.

Niestety, nieformalny charakter zespołów parlamentarnych sprawia do dziś, że zakres wiedzy na ich temat, w szczególności dotyczący konkretnych działań, jest bardzo ograniczony. Zespoły nie mają statusu organu Sejmu lub Senatu. Parlamentarzyści powinni jedynie poinformować Marszałka Sejmu o powołaniu zespołu. W efekcie, ten wycinek działalności parlamentarnej znajduje się poza obszarem obowiązkowego gromadzenia informacji przez Kancelarię Sejmu, a zespołom zapewnia się doraźne wsparcie np. w postaci udostępnienia przestrzeni konferencyjnej.

Ponadto, informacja zbiorcza o dokładnej liczbie zespołów w różnych kadencjach nie występuje $\mathrm{w}$ wykazie podstawowych parametrów działalności parlamentarnej ${ }^{28}$.

25 Warto nadmienić, że jedynym zespołem odnotowanym przez oficjalne źródła senackie był Senacki Zespół Strażaków.

26 Por. Zespoły, http://www.senat.gov.pl/sklad/senatorowie/zespoly/senackie.html (dostęp: 14.12.2014).

27 Zespół ten, ukonstytuowany w 19 grudnia 2007 roku, jest członkiem Europejskiej Międzyparlamentarnej Konferencji ds. Przestrzeni Kosmicznej i przez Kancelarię Sejmu został zaklasyfikowany do form działalności skierowanej na współpracę międzynarodową, podobną do grup bilateralnych. Patrz: Współpraca międzynarodowa Sejmu, http://orka.sejm.gov.pl/SQL.nsf/deleginna?OpenAgent\&22\&PL (dostęp: 12.01.2016).

28 Typowym zestawieniem tego rodzaju jest są prezentowane okresowo i po zakończeniu kadencji „Podstawowe dane statystyczne dotyczące prac Sejmu”. Por. Podstawowe dane statystyczne dotyczace prac Sejmu VI kadencji (5.11.2007-7.11.2011), http://orka.sejm.gov.pl/proc6.nsf/w-wykazy-sta/\$first?OpenDocument (dostęp: 12.01.2016). 
Ich liczbę należy rekonstruować na podstawie danych dostępnych w innych miej$\operatorname{scach}^{29}$.

Jeżeli chodzi o wiedzę na temat realnej działalności zespołów, okazała się ona bardzo ograniczona. Dostępne dane umożliwiają jedynie konfrontację zapisów regulaminowych z tytułami i datami spotkań. W nielicznych tylko przypadkach dostępne są zapisy całych lub części posiedzeń. Na tej podstawie możliwe jest jedynie określenie spójności przewidywań parlamentarzystów z ich faktycznymi działaniami co do częstotliwości spotkań.

$\mathrm{Na}$ potrzeby badania przeprowadzono rozmowę z pracownikiem obsługującym zespoły w kolejnej kadencji Sejmu i Senatu, dzięki czemu uzyskano również „Ramowy wzór regulamin zespołu parlamentarnego", który ostatecznie stał się dominującym kryterium oceny poziomu formalnej samoorganizacji posłów w poszczególnych zespołach. Nie udało się przy tym stwierdzić, czy był to jedyny tego rodzaju dokument udostępniony posłom w badanej kadencji.

Badanie miało charakter porównawczy i eksploracyjny. Analiza jakościowa służyła do typologizacji zespołów i do wyciągania wniosków na temat tendencji występujących w parlamencie lat 2007-2011 ${ }^{30}$. W celu eksploracji parlamentarnej samoorganizacji przyjęto otwartą strukturę procesu badawczego. Oznacza to, że wyniki analiz przeprowadzonych na wcześniejszych etapach determinowały kierunek analiz kolejnych. $\mathrm{Na}$ początku, przeprowadzono wstępną kwerendę zasobów sejmowych z punktu widzenia zakresu dostępności danych (w szczególności regulaminów zespołów parlamentarnych, liczby i treści posiedzeń oraz składów politycznych zespołów parlamentarnych).

Podczas analizy zebranych materiałów najpierw określono liczebność posłów w zespołach. Następnie, porównano składy zespołów ze składami klubów parlamentarnych. Metodami jakościowymi przestudiowane zostały regulaminy zespołów, pod kątem ich treści i struktury. Na tej podstawie wyróżniono główne osie analizy jakościowej i stworzono wstępny klucz kodowy, który dotyczył struktury i treści regulaminów zespołów. Na końcu zanalizowano częstotliwość posiedzeń zespołów.

Podczas badań przeprowadzono dwie fale kodowania uzyskanych materiałów, których efekty były powiązane. W pierwszym kroku uzyskano listę kategorii dotyczących: 1) ogólnych cech zespołów, 2) celów i zadań określonych explicité w regulaminach z wykorzystaniem kategorii orzecznikowych (np. animowanie działalności, budowanie autorytetu, dostosowywanie rozwiązań prawnych), 3) struktury władzy w zespole, 4) zasad i trybu podejmowania decyzji w zespole oraz 5) form pracy zespołów. W drugim kroku kodowania cele i zadania wtórnie zaklasyfikowano do kategorii systemowo-cybernetycznych wpisujących się w klasyfikację problemów zaproponowanej przez Mariana Mazura.

29 Źródłem dla VI kadencji Sejmu jest strona: Zespoły parlamentarne, http://orka.sejm.gov.pl/SQL.nsf/ listazesp?OpenAgent\&6 (dostęp: 12.01.2016).

30 Metody badań jakościowych, red. N.K. Denzin, Y.S. Lincoln, t. 1 i 2, Warszawa 2009. Por. W. Łukowski, O zastosowaniu podejścia jakościowego do badań nad polityką i politycznością, „Studia Politologiczne” 2009, nr 14, s. 34-51. 
Zaproponował on podział problemów na „poznawcze” i „decyzyjne”31. Klasyfikacja ta, pochodząca z pola cybernetyki, wydawała się spójna z koncepcją Williama Rosss Ashby’ego, ponieważ pozwoliła na interpretację założonego zaangażowania zespołów w proces podejmowania decyzji w instytucjach publicznych bez wnikania w zawiłości stosowanych w regulaminach odniesień.

W toku analizy regulaminów przyjęto ponadto, że założone działania zespołów mogły mieć charakter czysto poznawczy (np. zdobycie, pogłębienie wiedzy własnej lub jej popularyzacja w otoczeniu), decyzyjny ( $\mathrm{tj}$. skierowany na zmianę polityki państwa w określonym zakresie) bądź poznawczo-decyzyjny. Za działania o charakterze „poznawczym” uznano takie, które miały wspierać procesy komunikacyjne, zaś w regulaminie zespołu nie wyrażono woli wpływu na politykę państwa lub też konkretne decyzje władz publicznych. Działaniem o charakterze „decyzyjnym” było takie, które zostało przez posłów opisane w regulaminie jako skierowane na wpływ na politykę lub decyzje państwowe poprzez oddziaływanie na podmioty władzy publicznej i odpowiednie regulacje, oraz takie, które - nie definiując tak konkretnie podejmowanych działań - wskazywały polityczny kierunek działań. Z kolei działaniem „poznawczo-decyzyjnym” było takie, które sugerowało możliwość potencjalnego przełożenia wewnętrznych procesów komunikacyjnych (głównie o charakterze poznawczym) na oddziaływanie w sferze publicznej. Ponadto, wyróżniono kategorię celów i zadań trudnych do przyporządkowania do wspomnianych kategorii, na przykład ze względu na wysoki poziom ogólności zawartych w regulaminie sformułowań.

W trakcie analizy głównym kryterium oceny odrębności regulaminów zespołów był zakres podobieństwa dokumentu względem treści oraz struktury obecnej w regulaminie ramowym. W toku analizy wyróżniono kilka typów regulaminów, które parlamentarzyści decydowali się przyjąć za podstawę swojego działania. Na potrzeby badania stworzono klasyfikację, obejmującą trzy poziomy odstępstw (różnic) względem treści i struktury dokumentu ramowego. Przyjęto, że zespoły mogły modyfikować dokument ramowy w sposób minimalny, ograniczony oraz znaczący (tab. 1).

Tabela 1. Zakres różnic w treści i strukturze analizowanych regulaminów względem wzorca ramowego

\begin{tabular}{l|l|l|l}
\hline & \multicolumn{1}{|c|}{ Minimalny } & \multicolumn{1}{c|}{ Ograniczony } & \multicolumn{1}{c}{ Znaczący } \\
\hline Treść & $\begin{array}{l}\text { Ta sama treść paragrafów } \\
\text { i istotnie podobna treść } \\
\text { punktów (1T) }\end{array}$ & $\begin{array}{l}\text { Zmieniony tytuł paragrafu, } \\
\text { zmienione niektóre zapisy } \\
\text { punktów (2T) }\end{array}$ & $\begin{array}{l}\text { Zmieniona znaczna część } \\
\text { treści poszczególnych } \\
\text { punktów (3T) }\end{array}$ \\
\hline Struktura & $\begin{array}{l}\text { Ta sama kolejność } \\
\text { konkretnych paragrafów } \\
(1 S)\end{array}$ & $\begin{array}{l}\text { Zmieniona kolejność } \\
\text { paragrafów; niektóre } \\
\text { paragrafy dodane, } \\
\text { niektóre usunięte (2S) }\end{array}$ & $\begin{array}{l}\text { Zupełnie inna forma } \\
\text { porządkowania treści } \\
\text { wanalizowanym } \\
\text { regulaminie (3S) }\end{array}$ \\
\hline
\end{tabular}

Źródło: Opracowanie własne na podstawie badań regulaminów zespołów poselskich i parlamentarnych Sejmu VI i Senatu VII kadencji.

31 Patrz M. Mazur, Cybernetyka i charakter, Warszawa 1976, s. 99-116. 
Analiza wykazała, że największa liczba zespołów przyjęła regulamin, który w sposób minimalny modyfikował jego sugerowaną formę (1T i 1S). Było ich 36. Mniejsza część zespołów (14) zmodyfikowała treść i strukturę dokumentu wyjściowego w sposób ograniczony ( $2 \mathrm{~T}$ i $2 \mathrm{~S}$ ). Natomiast pozostałe zespoły (16) albo zmieniły pierwotny regulamin w znaczącym zakresie, albo całkowicie opisały reguły działania na swój sposób (3T i 3S).

$\mathrm{W}$ efekcie przyporządkowania poszczególnych regulaminów do odpowiednich typów można było poszukiwać wiedzy o tym, jakimi konkretnymi treściami poszczególne zespoły wypełniały regulaminy. Innymi słowy, co w istocie różniło badane regulaminy zespołów.

\section{Zespoły jako forma samopołączenia dotąd niezależnych od siebie w określonym wymiarze posłów i senatorów}

Jak się okazało, w mniej niż połowie przypadków (28) zespoły miały charakter poselski, to znaczy nie było w nich żadnego senatora. Od 1 do 3 senatorów było w 19 zespołach. W takiej samej liczbie zespołów było 4 i więcej senatorów. Przy tym, tylko w 6 przypadkach było ich więcej niż 10 .

We wszystkich regulaminach zawarto zapis, według którego członkostwo nabywało się na zasadzie dobrowolności. Wydaje się również, że relatywnie wiele zespołów zawarło wszystkie wyróżnione w toku analizy regulaminów warunki członkostwa (tzn. „apolityczność zespołu”, „dobrowolność przynależności”, „zainteresowanie problematyką” $\mathrm{i}$ „wyrażenie akcesu”). Przy tym jedynie w kilku przypadkach posłowie zamieścili dodatkowe kryteria członkostwa. Można było je określić jako: „organizacyjne” (przynależność do związków zawodowych i Ochotniczej Straży Pożarnej) i „statusowe” (funkcja profesora wyższej uczelni). Wydaje się zatem, że właśnie bardzo luźne potraktowanie warunków członkostwa i podkreślanie jego dobrowolności, pozwala na uznanie działalności w zespołach parlamentarnych jako opartych na mechanizmach samoorganizacyjnych.

Zespoły były też zróżnicowane pod względem liczebności. Jeżeli za kryterium podziału przyjąć liczbę 15 (taka liczba posłów pozwala na przykład na stworzenie klubu poselskiego i na złożenie projektu ustawy), to najwięcej było bardzo małych i małych zespołów (po 26). Średnich zespołów było 12. Natomiast zespołów dużych i bardzo dużych, które zrzeszały więcej niż 10\% składu Sejmu, było łącznie 8 .

Interesujące wydaje się zestawienie zespołów parlamentarnych na podstawie kryterium członkostwa w układzie parlamentarnym: koalicja rządząca-opozycja. W zdecydowanej większości (53), członkowie pochodzili z różnych stron układu parlamentarnego. Zespołów, których członkami byli jedynie posłowie koalicji rządzącej (PO-PSL), było 9. Zespołów, w których działali wyłącznie posłowie opozycji, było 4 . Aż w 45 przypadkach w zespole dominowali jednak posłowie $\mathrm{PO}$, a jedynie w 15 zespołach grupą dominującą był PiS. Z kolei w 6 przypadkach największą liczebnie grupę stanowili posłowie SLD lub PSL. 


\section{Zespoły jako forma celowego działania posłów i senatorów w otoczeniu parlamentarnym}

Cele i zadania zespołów były definiowane przez posłów bardzo różnie. Najczęściej regulaminy obejmowały kilka celów i (lub) zadań. Dlatego w trakcie analizy można było wyróżnić jej wiele wymiarów. Niekiedy cele były umieszczane w oddzielnym paragrafie regulaminu. W innych przypadkach włączono je do opisu kryteriów członkostwa w zespole.

Spośród 66 zespołów, aż 54 określiło swoje cele w odniesieniu do całego kraju, 8 do regionu, natomiast 4 do otoczenia międzynarodowego. Problematykę podejmowaną przez zespoły można było przy tym, zaklasyfikować do trzech kategorii - gospodarczej, polityczno-instytucjonalnej i społecznej.

Wyniki analizy wskazują, że posłowie w równym stopniu byli zainteresowani zdobywaniem i rozpowszechnianiem wiedzy na temat rozmaitych zagadnień (41), co wpływaniem na politykę państwa w interesującym ich zakresie (42). Aż w 52 regulaminach znalazły się jednak zapisy, które mogą być odczytywane jako działalność „na pograniczu", to znaczy łączące aspekty poznawcze i decyzyjne. Tylko w 18 przypadkach cele były trudne do zaklasyfikowania. Uwagę zwraca natomiast wysoki poziom ogólności zapisów. Dotyczyło to zarówno celów i zadań, jak i docelowych grup oddziaływania czy też przewidywanych działań w sferze publicznej.

Najpopularniejszym celem o charakterze poznawczym była „promocja” lub „upowszechnianie" problematyki będącej w obszarze zainteresowania członków zespołu (40), w tym idei, wiedzy, postaw, kultury i wartości, zasad czy dobrych praktyk. Zdecydowanie najmniej popularna była działalność edukacyjna. Szczególną kategorią celów, którą posłowie zapisali w regulaminach, było tworzenie przestrzeni komunikacyjnej dla wymiany bądź starcia poglądów (5). W około $1 / 3$ przypadków w regulaminach zawarto też wskazówkę na temat grupy docelowej dla działań informacyjno-promocyjnych. Mieli to być przede wszystkim: parlamentarzyści (8 przypadków) oraz społeczeństwo, media i opinia publiczna (11 przypadków).

W grupie, których cele zostały zaklasyfikowane w toku analizy do kategorii poznawczo-decyzyjnej, znalazło się najwięcej zespołów. Przy tym najczęściej parlamentarzyści decydowali się na włączanie $\mathrm{w}$ działalność innych podmiotów zajmujących się poszczególnymi kwestiami ( 55 zespołów). Miały to być z jednej strony organizacje społeczne (32) i samorządy (10), z drugiej zaś główne organy parlamentarne i instytucje państwowe.

Parlamentarzyści w różny sposób chcieli też włączać zespoły w procesy o charakterze decyzyjnym. Jednocześnie, w regulaminach wskazywali, że ich zadaniem może być działanie o charakterze reaktywnym bądź proaktywnym. Wolę wpływu na decyzje w sferze publicznej w zakresie regulacji wspomniano w 28 przypadkach. Z kolei wpływ na konkretne podmioty $\mathrm{w}$ sferze publicznej był przewidywanym sposobem działania dla 26 zespołów. 
Co do aktywności, to rzeczywista częstotliwość posiedzeń zdecydowanie rozminęła się z zapisanymi w regulaminach oczekiwaniami. Jeżeli za kryterium odniesienia przyjąć częstotliwość najczęściej występującą w regulaminach (tj. że rocznie powinno odbywać się co najmniej 4 spotkania, co oznacza, że w kadencji powinno być ich co najmniej 16), to jedynie 5 zespołom udało się osiągnąć przewidywaną częstotliwość posiedzeńn ${ }^{32}$. Reszta zespołów nie spotykała się tak często jak przewidywała.

\section{Podsumowanie}

Mimo ograniczonych zasobów źródłowych, opis zespołów parlamentarnych jako działalności samoorganizacyjnej parlamentarzystów wydaje się uzasadniony, podobnie jak odpowiedź twierdząca na zadane we wprowadzeniu pytanie. Posłowie potrafią współpracować na innych podstawach niż „partyjno-klubowe” (rozumiane formalnie), choć bardzo często ich cele również mają charakter polityczny. Po pierwsze, na poziomie teoretycznym, sformułowane przez Williama Rossa Ashby’ego kategorie wydają się adekwatne do opisu parlamentaryzmu. Możliwe jest bowiem przyporządkowanie wyróżnionych teoretycznie kategorii do form działalności posłów i senatorów. Istnieją elementy (posłowie i senatorowie), które organizują się w inne struktury niż przewidziane w Regulaminie Sejmu i Senatu, a określane jako polityczne (kluby) czy też instytucjonalne (organy, takie jak komisje). Po drugie, wyniki badania empirycznego pokazują, że - wbrew rozpowszechnionym opiniom - polscy parlamentarzyści mimo wszystko współdziałają w forach innych niż partyjno-klubowe i innych niż organach parlamentu. Można więc powiedzieć, że dysponują przestrzenią działania nie w pełni zdeterminowaną przez kluby, mimo że jest ona bardzo specyficzna i wąska.

W szczególności, wyniki analizy zespołów parlamentarnych pokazały, że są one wyjątkową w polskim parlamencie formą działania, która — przynajmniej czysto formalnie - pozwala posłom na zrzeszanie się w sposób dobrowolny i pozapolityczny. Przy tym zrzeszenie to może być nakierowane na cele czysto poznawcze albo też na formułowanie postulatów w sferze politycznej. Jednocześnie, ogromne zróżnicowanie celów i zadań zespołów, zarówno w odniesieniu do poziomu regionalnego, ogólnokrajowego, jak i międzynarodowego, świadczy o tym, że posłowie mieli dużą autonomię w opisywanym zakresie.

W dominującej części , członkami zespołów byli parlamentarzyści pochodzący z różnych ugrupowań politycznych i z obu izb. Ponadto, o samoorganizacyjnym charakterze zespołów parlamentarnych świadczy fakt, że we wszystkich regulaminach podkreślany był woluntarystyczny charakter członkostwa w apolitycznym zespole, w skład którego można było wejść po spełnieniu bardzo luźno sformułowanych warunków.

32 Były to: Zespół ds. Energetyki, Parlamentarny Zespół ds. Współpracy z Organizacjami Pozarządowymi, Parlamentarny Zespół ds. Osób Niepełnosprawnych, Parlamentarny Zespół Przyjaciół Zwierząt oraz Parlamentarny Zespół ds. zbadania przyczyn katastrofy TU-154 M z 10 kwietnia 2010 roku. 
Jednocześnie, okazało się jednak, że kontekst instytucjonalny wyrażony w istnieniu ramowego wzoru regulaminu zespołu parlamentarnego wyznaczył kierunek myślenia dominującej części organizujących się parlamentarzystów. Trudno jest przy tym stwierdzić, na ile przyjęcie już istniejących rozwiązań regulaminowych wynikało z konieczności, a na ile z nieprzymuszonej woli funkcjonowania w istniejącej strukturze formalnej parlamentu. Można domniemywać, że regulaminy mogły być traktowane nie tyle jako ramy, ile punkt orientacyjny dla działań parlamentarzystów w zespołach, zwłaszcza że przewidywana w regulaminach częstotliwość spotkań była bardzo różna od faktycznej. Jest to hipoteza, która - jeżeli zostałaby zweryfikowana pozytywnie - wtórnie świadczyłaby o istnieniu w parlamencie wolnej przestrzeni działania. Warto się jednocześnie zastanowić nad tym, w jaki sposób formalne zapisy regulaminowe przekładały się na wewnętrzne funkcjonowanie zespołów $\mathrm{i}$ jak przewidziana w nich struktura władzy przekładała się na działalność w otoczeniu społecznym i politycznym.

O ile formalna wolna przestrzeń działania została zdefiniowana i jej część zbadana, o tyle na podstawie przeprowadzonej analizy nie można stwierdzić, na ile członkostwo w poszczególnych zespołach było wynikiem własnej woli parlamentarzystów, a na ile był to rezultat zapotrzebowania lub rekomendacji wyrażonych ze strony władz klubu lub koła. Bez odpowiedzi pozostają zatem ewentualne pytania dotyczące faktycznych źródeł i charakteru działania w zespołach przez parlamentarzystów. Nie można także jeszcze stwierdzić, czy w rzeczywistości posłowie podejmowali zadeklarowane w regulaminach wysiłki względem instytucji publicznych i na ile wpisywało się w tendencję występującą $\mathrm{w}$ ich klubie lub kole parlamentarnym. Wszystkie te aspekty działalności zespołów parlamentarnych stanowią konieczny kierunek dalszych badań polskiego parlamentaryzmu w odniesieniu do problemu samoorganizacji.

\section{Bibliografia}

Antoszewski A., Herbut R., Systemy polityczne współczesnego świata, Arche, Gdańsk 2001.

Antoszewski A., Wzorce rywalizacji politycznej we współczesnych demokracjach europejskich, Wydawnictwo Uniwersytetu Wrocławskiego, Wrocław 2004.

Ashby W.R., Principles of Self-Organizing System, [w:] Principles of Self-Organization, red. H. von Foerster, G.W., jr. Zopf, John Wiley and Sons, New York 1961.

Bailey K.D., Sociology and the new systems theory: Toward a theoretical synthesis, Albany, New York 1994.

Birch A.H., The Concepts and Theories of Modern Democracy, Routledge, London-New York 1995.

Colomer J.M., Disequlibrium institutions and pluralist democracy, „Journal of Theoretical Politics” 13, 2001, nr 3.

Dudzińska A., System zamknięty. Socjologiczna analiza procesu legislacyjnego, Scholar, Warszawa 2015.

Duverger M., Political Parties. Their Organization and Activity in the Modern State, London: Methuen, New York: Wiley, New York-London-Sydney 1965.

Dzisiów-Szuszczykiewicz A., „Arabska wiosna” - przyczyny, przebieg i prognozy, „Bezpieczeństwo Narodowe" 2011, nr 18.

Easton D., A Systems Analysis of Political Life, University of Chicago Press, Chicago-London 1979.

Haken H., Synergetics. An Introduction, Springer-Verlag, Berlin-Heidelberg-New York-Tokyo 1983.

Kaczmarek B., „Politologia organizacji”? „Organizatologia polityki”? Polityka w świecie organizacji i organizacyjny sens polityki a ich badanie, „Studia Politologiczne” 2010, nr 17. 
Katz R., Mair P., Changing models of party organization and party democracy, „Party Politics” 1, 1995, nr 1.

Key V.O. Jr., Politics, Parties, and Pressure Groups, Thomas Y. Crowell Company, New York 1958.

Konstytucja Rzeczypospolitej Polskiej z dnia 2 kwietnia 1997 r., Dz. U. 1997 Nr 78 poz. 483.

Łukowski W., O zastosowaniu podejścia jakościowego do badań nad polityka i politycznością, „Studia Politologiczne" 2009, nr 14.

Machelski Z., Modele parlamentów dwuizbowych. Ujęcie porównawcze, „Wrocławskie Studia Politologiczne” 2012, nr 12.

Manin B., The Principles of Representative Government, Cambridge University Press, Cambridge 1997.

Mazur M., Cybernetyka i charakter, Państwowy Instytut Wydawniczy, Warszawa 1976.

Metody badań jakościowych, red. N.K. Denzin, Y.S. Lincoln, t. 1 i 2, Wydawnictwo Naukowe PWN, Warszawa 2009.

Michels R., „Oligarchiczne tendencje organizacji”, [w:] Władza i społeczeństwo, red. J. Szczupaczyński, Scholar, Warszawa 1995

Muszyński J., Procedury zarzadzania w partiach politycznych, Duet, Toruń 2004.

Nohlen D., Prawo wyborcze i system partyjny. O teorii systemów wyborczych, Scholar, Warszawa 2004.

Obciążeni polityką. Posłowie i partie, red. W. Wesołowski, IFiS PAN, Warszawa 2001.

Sobolewska-Myślik K., Kosowska-Gąstoł B., Borowiec P., Struktury organizacyjne polskich partii politycznych, Wydawnictwo Uniwersytetu Jagiellońskiego, Kraków 2010.

Veenendaal Wouter P., How democracy Functions Without Parties: The Republic of Palau, „Party Politics”, tom 22, 2016, nr 1 .

Weinberg G.M., Myślenie systemowe, Wydawnictwo Naukowo-Techniczne, Warszawa 1979.

Wybrane aspekty funkcjonowania Sejmu w latach 1997-2007, red. J. Sokołowski, P. Poznański, Oficyna Wydawnicza AFM, Kraków 2008.

Zachowania polityczne, red. R. Dalton, H.D. Klingemann, R. Markowski, t. 1 i 2, Wydawnictwo Naukowe PWN, Warszawa 2010.

Zelený M., Hufford K.D., The ordering of the unknown by causing it to order itself, „International Journal of General Systems" 21, 1992.

Zubek R., Goetz K.H., Stecker Ch., Sprawny parlament: wpływ partii i reguł na przewidywalność legislacyjna, Raport z badań Ernst \& Young Polska Sp. z o.o., Warszawa 2009.

\section{Źródła internetowe}

Archiwum Sejmu Online, Zespoły parlamentarne, http://www.sejm.gov.pl/sejm7.nsf/agent.xsp?symbol=ZESPOLY\&NrKadencji $=7$

Mielczarek A., Ruch „Solidarności” w świetle teorii ruchów społecznych, Tekst zaprezentowany na seminarium „Solidarność - nowe podejścia do analizy ruchu społecznego", Collegium Civitas, Warszawa, http://www.civitas.edu.pl/pub/nasza_uczelnia/seminarium_solidarnosc/Mielczarek-tekst-9.01.pdf

$\mathrm{ml}$, iar, Opiekunowie niepełnosprawnych pójdą pod Sejm!, http://www.fakt.pl/protest-opiekunow-niepelnosprawnych-doroslych,artykuly,452132,1.html, 26.03.2014

paziem, Droga do ocalenia Polski jest samoorganizacja i samoobrona Polaków! „Wierni Polsce”, https://wiernipolsce.wordpress.com/2012/01/25/droga-do-ocalenia-polski-jest-samoorganizacja-i-samoobronapolakow/, 25.01.2012

Podstawowe dane statystyczne dotyczace prac Sejmu VI kadencji (5.11.2007-7.11.2011), http://orka.sejm.gov. $\mathrm{pl} /$ proc6.nsf/w-wykazy-sta/\$first?OpenDocument

Sadura P., Samoorganizacja się sama nie zrobi, „Krytyka Polityczna”, http://www.krytykapolityczna.pl/Teksty-poza-KP/Sadura-Samoorganizacja-sie-sama-nie-zrobi/menu-id-129.html, 02.02.2010

Uchwała Sejmu Rzeczypospolitej Polskiej z dnia 30 lipca 1992 r. Regulamin Sejmu Rzeczypospolitej Polskiej, wg stanu prawnego po zmianie $\mathrm{z}$ dnia 19 grudnia 2014 r. - M.P. 2015 poz. 550, http://www.sejm. gov.pl/prawo/regulamin/kon7.htm 
Uchwała Senatu Rzeczypospolitej Polskiej z dnia 23 listopada 1990 r. Regulamin Senatu. Tekst ujednolicony opracowany na podstawie Monitora Polskiego z 2014 r. poz. 529 i 707 oraz z 2015 r. poz. 373, file:///C:/ Users/admin/Downloads/regulamin2015.pdf

Współpraca międzynarodowa Sejmu, http://orka.sejm.gov.pl/SQL.nsf/deleginna?OpenAgent\&22\&PL

Zespoly, http://www.senat.gov.pl/sklad/senatorowie/zespoly/senackie.html

Zespoly parlamentarne, http://orka.sejm.gov.pl/SQL.nsf/listazesp?OpenAgent\&6

\section{Parliamentary teams as forms of deputies' self-organization. The results of a Polish exploratory study}

Keywords: parliamentary teams, self-organization, parliamentarians, Poland

Summary

In the article I present the results of an exploratory study of Polish parliament based on the concept of self-organizing systems formulated by W. Ross Ashby. This conceptual framework seems useful for parliamentary studies as it helps to determine the necessary conditions for a group to be a self-organizing system. The study shows that Polish parliamentary teams could be included into this category.

The empirical part of the study utilized data regarding the Polish Sejm and Senate between 2007 and 2011. Internal regulations of the teams, their party composition and activities have been studied with the use of qualitative research tools. 